\title{
Gas Output Problem
}

National Cancer Institute

\section{Source}

National Cancer Institute. Gas Output Problem. NCI Thesaurus. Code C63109.

Problem associated with gas output. 